\title{
子宮内膜症合併不妊における腹腔鏡下手術後の妊娠予後の検討
}

高知大学産科婦人科

\author{
泉谷知明、谷口佳代、前田長正、深谷孝夫
}

\section{Efficacy of laparoscopic surgery for endometriosis-associated infertility}

\author{
Chiaki Izumiya, Kayo Taniguchi, Nagamasa Maeda, Takao Fukaya \\ Department of Obstetrics and Gynecology, Kochi Medical School
}

\begin{abstract}
Objective: To evaluate the efficacy of laparoscopic surgery for endometriosis-associated infertility.
Design: Retrospective study.

Setting: Department of Obstetrics and Gynecology, Kochi Medical School.

Patient(s): Sixty-five women with endometriosis-associated infertility.

Intervention(s): Laparoscopic evaluation and treatment of endometriosis.
\end{abstract}

Main outcome Measure(s): Background of 65 women with endometriosis-associated infertility. Clinical pregnancy rate (PR) of 57 women, who were followed $>6$ months after laparoscopic surgery for endometriosis.

Result: Of 57 women who underwent laparoscopic surgery, 34 conceived (clinical PR, 59.6\%), including 28 non-ART pregnancies and 6 ART pregnancies. Eighty percent of non-ART pregnancies conceived within 1 year after laparoscopic surgery. In women with minimal and mild endometriosis, the clinical PR of non-ART after laparoscopic surgery was $61.1 \%$, and in women with moderate and severe endometriosis the clinical PR of non-ART was $43.8 \%$. The clinical PR of non-ART in women $<35$ years of age $(67.6 \%)$ was significantly higher than in older women $(27.2 \%)$.

Conclusion: Women with endometriosis-associated infertility can be expected to conceive spontaneously within 1 year after laparoscopic surgery. When patients fail to conceive 1 year after laparoscopic surgery, ART should be considered.

Key Words: endometriosis, infertility, laparoscopic surgery

\section{【はじめに】}

子宮内膜症は生殖年齢女性に発症し、月経痛な どの疼痛をきたすだけでなく、その約半数に不妊 を合併することから、女性のQOLを著しく低下さ せる疾患である。日本産科婦人科学会の『子宮内 膜症取扱い規約』では子宮内膜症合併不妊症例に 対してはまず腹腔鏡などによる手術療法を行い、 その後卵管の状態や年齢によって治療法を選択す ることが推奨されている1）。今回、当科における 子宮内膜症合併不妊の管理を考察するため、腹腔 鏡下に子宮内膜症の診断、治療を行った症例の妊 娠予後について検討した。

\section{【対象と方法】}

当科では、月経痛などの疼痛症状がNSAIDsで
コントロール困難なものや疼痛症状に不妊を伴う もの、内診でダグラス窩に圧痛を伴う硬結を認め るもの、画像所見で卵巣チョコレート襄胞が疑わ れるものに対して、子宮内膜症の確定診断および 治療を目的とした腹腔鏡下手術を行う方針として いる。1999年 1 月から 2008年12月までの間に、こ の方針に沿って当科で子宮内膜症に対して腹腔鏡 下手術を施行したものは312例であった。

今回の検討では、挙児希望があり避妊をしない 性生活を 1 年以上送りながら妊娠しない症例を不 妊例としたが、子宮内膜症に対して腹腔鏡下手術 を行った 312 例のうち不妊を合併していたものは79 例（25.3\%）であった。腹腔鏡下手術の妊孕性改 善に対する有用性を検討するため、男性因子・排 卵障害といった他の不妊因子を有した症例と、腹 腔鏡施行時に両側卵管閉塞が確認された症例を除 
外した。この条件を満たしたのは79例のうち65例 で、これを今回の検討の対象とした。

腹腔鏡下手術は、妊孕性改善のため可及的な病 巣除去と癒着により変位した子宮付属器を解剖学 的に正常な位置に戻すことを目標とし、全例気腹 法で表 1 に示すような術式を行った。卵巣チョコ レート襄胞に対しては、囊胞摘出を基本としてい るが、比較的小さく（囊胞径 $3 \mathrm{~cm}$ 未満）卵巣実質 と囊胞壁の剥離が困難なものでは囊胞壁焼灼を行 った。

表 1 施行した術式

\begin{tabular}{cc}
\hline 病巣焼灼術 & 30 例 \\
癒着剥離術 & 38 例 \\
チョコレート襄胞 & \\
内腔焼灼術 & 16 例 \\
襄胞摘出術 & 30 例 \\
付属器切除 & 1例 \\
\hline &
\end{tabular}

対象とした65例で、その背景を検討し、さらに 65例中術後 6 力月以上追跡可能であった 57 例の術 後妊娠予後について、後方視的に検討した。統計 学処理は $\chi 2$ 検定、Student-t検定、ステップワイ ズ重回帰分析で行い、 $\mathrm{p}<0.05$ 有意差ありとした。

\section{【結果】}

\section{(1) 対象の背景}

対象とした 65 症例の背景を表 2 に示す。平均年 齢は32.0 03.8 歳で、平均不妊期間は $48.6 \pm 37.5$ 力月、 原発性不妊は49例 $(75.4 \%) 、$ 続発性不妊は16例 (24.6\%) であった。同時期に腹腔鏡下手術を行っ た子宮内膜症症例で、疼痛もしくはチョコレート

表 2 対象の背景

\begin{tabular}{cc}
\hline 平均年齢（歳） & $32.0 \pm 3.8$ \\
平均不妊期間（月） & $48.6 \pm 37.5$ \\
R-ASRMスコア（点） & $41.4 \pm 34.7$ \\
R-ASRM進行期（例） & \\
I 期 & 12 \\
II 期 & 8 \\
III期 & 17 \\
IV期 & 28 \\
付属器癒着スコア（点） & \\
卵管 & $2.73 \pm 7.51$ \\
卵巣 & $7.44 \pm 9.71$ \\
卵管+卵巣 & $9.73 \pm 15.63$ \\
チョコレート襄胞あり（例） & 44 \\
\hline
\end{tabular}

囊胞の指摘を主訴とした症例と、R-ASRM分類の 進行期および点数 ·付属器癒着スコア・卵巣チョ コレート襄胞の有無について比較したが、いずれ も有意差はなく、不妊症例に特徵的な内膜症病変 の同定はできなかった。

(2) 術後の不妊治療

当科における腹腔鏡下術後の不妊治療の方針と しては、待機療法（タイミング指導含む）・調節 性卵巣刺激 (COS) - COS併用の人工授精 (COS+AIH) ・ ARTの順にstep upしていくこと を基本としている。各治療を何周期行うかは、年 齢や不妊期間、手術前の不妊治療内容を考慮し決 定している。

術後 6 カ月以上追跡可能であった57例（平均追 跡期間は16.3 14.4 力）に执いて、実際に行われ ていた不妊治療としては、待機療法のみが28例、 COSは20例、COS + AIHが17例、最終的にARTに いたったものが 9 例であった（重複あり）。step upまでの施行周期数は、待機療法が $1 \sim 8$ 周期、 $\operatorname{COS}$ が $1 \sim 6$ 周期、 $\operatorname{COS}+\mathrm{AIH}$ が $1 \sim 7$ 周期であ った。

ARTを行った症例とART行わなかった症例の 背景を比較したところ、ART施行例では年齢が有 意に高く（33.7 \pm 4.0 歳 v.s. $31.0 \pm 3.41$ 歳 $)$ 、不妊期 間が有意に長かった（71.6 \pm 49.1カ月 v.s. $31.8 \pm$ 22.4 月)。また、日本産科婦人科学会の『子宮内 膜症取扱い規約』で早期のARTへのstep upが推 奨されている38歳以上または35歳以上の $\mathrm{I}$ 期症例 は 9 例であったが、このうちARTを希望した症例 は 3 例のみで、いずれも術後 6 力月以内にARTを 開始していた。

(3) 術後妊娠率

術後 6 力月以上追跡可能であった 57 例で、腹腔 鏡下手術後の妊娠予後を検討した。術後妊娠成立 したものは34例 (59.6\%) で、妊娠方法の内訳は、 自然妊娠（タイミング療法を含む）23例、調節性 卵巣刺激（COS） 5 例、ARTが 6 例であった。

子宮内膜症の重症度により軽症群（R-ASRM I 期 + II 期18例） と重症群（R-ASRM III 期 + IV 期 39 例）にわけ、術後妊娠率を比較した（表 3 )。軽 症群に比べ重症例の術後妊娠率は有意に低かった が、ARTによる妊娠例を除くと術後妊娠率は両群 間で有意差を認めなかった。

また、ART以外の妊娠例の累積妊娠率（図）で は、軽症群・重症群ともに術後 6 力月までに半数 以上が妊娠し、さらに術後 1 年までに両群とも約 80\%が妊娠成立していた。 
(4) 妊娠予後に関与する因子

術後 6 力月以上追跡可能であった 57 例のうち、 ARTを施行した 9 例を除いた 48 例を、妊娠成立症 例（妊娠例28例）と妊娠に至らなかった症例（非 妊娠例20例）にわけ、妊娠に影響すると考えられ る因子として年齢・不妊期間・R-ASRM分類の点

表 3 術後妊娠率

\begin{tabular}{ccc}
\hline & 術後妊娠率 & ARTを除いた妊娠率 \\
\hline $\begin{array}{c}\text { 軽症 } \\
(n=18)\end{array}$ & $77.8 \% 7$ & $61.1 \%$ \\
$\begin{array}{c}\text { 重症 } \\
(n=39)\end{array}$ & $51.3 \%$ & $43.8 \%$ \\
$\begin{array}{c}\text { 全体 } \\
(n=57)\end{array}$ & $59.6 \%$ & $49.1 \%$ \\
\hline
\end{tabular}

$(* \mathrm{p}<0.05)$

図 累積娃娠率

(\%)

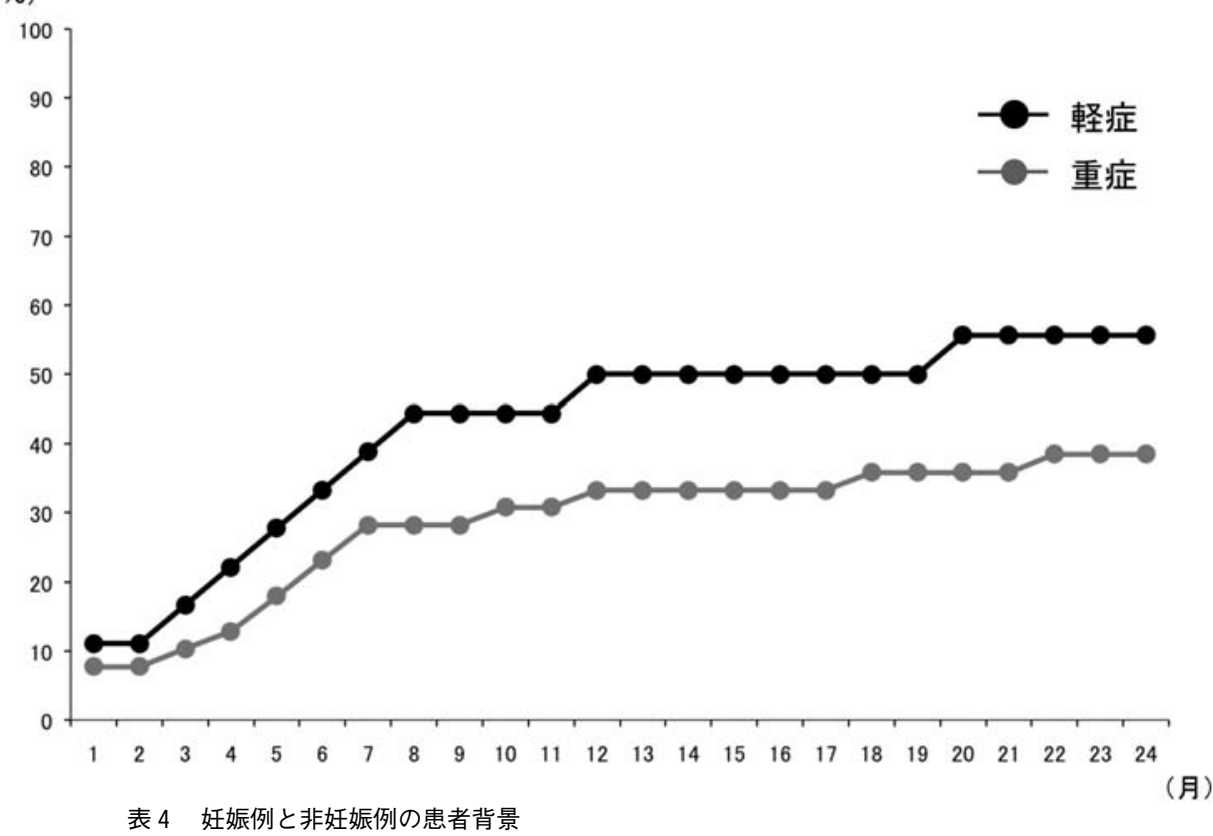

数および卵管・卵巣の癒着スコア・卵巣チョコレ 一ト囊胞の有無を比較検討した（表 4 ）。

その結果、年齢は両群間で有意差はなく、不妊 期間は非妊娠例で長い傾向を認めたが有意差はな かった。またR-ASRM分類の点数および卵管・卵 巣の癒着スコアは、非妊娠例で高い傾向を認めた が有意差はなかった。また、ステップワイズ重回 帰分析を用いて妊娠成立に寄与する因子を検討し たところ、卵巣チョコレート震胞の有無が抽出さ れ、チョコレート襄胞が存在しそれに対し手術療 法を行った症例で、術後妊娠予後が不良となると いう結果であった。

そこで、チョコレート襄胞に関して、さらにそ の局在と施行した術式についての検討を行った。 その結果を表 5 に示すが、術後妊娠率は、チョコ レート震胞が片側性の症例と両側性の症例の間に 有意差はなく、また囊胞摘出術施行例と内腔焼灼 術施行例との間にも有意差はなかった。

\begin{tabular}{lcc}
\hline & 妊娠例 $(n=28)$ & 非妊娠例 $(n=20)$ \\
\hline 年齢（歳） & $30.9 \pm 3.1$ & $32.9 \pm 4.6$ \\
不妊期間 (月) & $37.7 \pm 26.1$ & $49.1 \pm 45.0$ \\
R-ASRMスコア (点) & $34.9 \pm 29.2$ & $41.1 \pm 33.5$ \\
付属器癒着スコア（点） & & \\
$\quad$ 卵管 & $1.30 \pm 3.69$ & $1.85 \pm 5.57$ \\
$\quad$ 卵巣 & $6.09 \pm 8.33$ & $8.08 \pm 8.87$ \\
$\quad$ 卵管+卵巣 & $6.52 \pm 10.44$ & $9.92 \pm 13.67$ \\
チョコレート襄胞（例） & & 5 \\
両側 & 5 & 11 \\
片側 & 11 & (全てn.s.)
\end{tabular}


表 5 卵巣チョコレート衰胞の局在および襄胞に対する術式と術後 妊娠率

\begin{tabular}{|c|c|c|c|}
\hline \multicolumn{4}{|c|}{ 術後妊娠率 } \\
\hline & & 囊胞摘出 & 内腔焼灼 \\
\hline 片側性 & $39.1 \%$ & $41.1 \%$ & $33.3 \%$ \\
\hline 両側性* & $42.8 \%$ & $50.0 \%$ & 33. $3 \%$ \\
\hline
\end{tabular}

* : 両側性の症例は、両側とも同一の術式を行った症例のみとした

妊娠予後に関与する因子として、年齢および不 妊期間についてさらに検討を加えた（表 6 ）。年 齢については35歳未満と35歳以上とで比較したが、 術後妊娠率は35歳未満で $67.6 \%$ 、35歳以上で $27.2 \%$ であり、両者に有意差を認めた。不妊期間につい ては 4 年末満とそれ以上とで比較したところ、術 後妊娠率は 4 年以下のものでは65.5\%、4 年以上で は 47.4\%と不妊期間が短いもので術後妊娠率は高か ったが、統計学的有意差は認めなかった。

表 6 年齢・不妊期間と術後妊娠率

\begin{tabular}{|c|c|c|c|}
\hline 年齢 & 術後妊娠率 & 不妊期間 & 術後妊娠率 \\
\hline$<35$ 歳 & $67.6 \%$ & $<48$ 力月 & $65.5 \%$ \\
\hline \multicolumn{4}{|c|}{$*$} \\
\hline 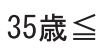 & $27.2 \%$ & 48 力月 $\leqq$ & $47.4 \%$ \\
\hline
\end{tabular}

\section{【考察】}

2004年に日本産科婦人科学会より『子宮内膜症 取扱い規約 第 2 部治療編・診療編』が発行され、 子宮内膜症不妊患者の治療方針が示された。2010 年 1 月にその第 2 版が発行されたがその治療方針 は同様であり、軽症例での待機療法の期間は 3 か ら 6 力月とし、待機療法で妊娠成立しなかった軽 症例扮よび37歳以下の重症例でCOSもしくはCOS 併用のIUIを 3 から 4 周期ずつ行うことが推奨され ている。さらに、卵管癒着が高度のもの、38歳以 上もしくは35歳以上の IV 期症例では、早期の ART を考慮すべきとしている。今回の対象とした症例 には取扱い規約が発行される以前の症例も多く含 まれていたが、その治療内容を検討したところ、 待機療法は最長で 8 周期であり、またCOSもしく はCOS併用のIUIを行った期間は 7 周期までであ り、ほぼこの治療方針に沿った形で行われていた。
子宮内膜症が妊孕性を低下させる要因となるこ とは、多くの疫学的デー夕により示されているが、 子宮内膜症による妊孕性低下のメカニズムは十分 に解明されていない。このため、現在のところ子 宮内膜症に伴う不妊に対する普遍的治療法は確立 されてはいないが、日本産科婦人科学会だけでな 〈ESHRE $^{2)}$ やASRM ${ }^{3)}$ といった国際的な学会から もこれまでに得られたエビデンスをもとにした治 療ガイドラインが示されている。腹腔鏡下手術の 有用性は、軽症例において明らかとされており また重症例においてはRCTがなく明らかな有用性 を示すエビデンスはないものの、いずれのガイド ラインも可及的な病巣除去を推奨している。今回 の検討でも、軽症例の術後妊娠率は60\%以上と高 率であり、また重症例であっても約 $40 \%$ A゙ART以 外の方法で妊娠成立していることから、腹腔鏡下 手術が妊孕性改善に有用と考えられた。

術後の不妊治療は、年齢・子宮内膜症の重症 度・卵管の状態・他の不妊因子の有無などから 個々に決定することとなるが、ポイントとなるの は早期のARTを考慮する症例の選択およびART へのstep up時期の決定である。このポイントを明 確にするには、どのような症例でどのくらいの期 間ART以外の方法で妊娠が期待できるのかを検討 することが必要である。子宮内膜症による不妊に おける妊娠予後を検討した複数の報告 ${ }^{6-8)}$ がある が、年齢・不妊期間 - 付属器癒着が妊娠予後に関 与する因子とされている。

まずART以外の方法による妊娠を期待できる期 間については、今回の検討で、軽症例・重症例と もにART以外での妊娠成立例の半数以上が 6 力月 以内であり、さらにその $80 \%$ が術後 1 年以内であ ったことから、ART以外での妊娠成立を試みる期 間としては術後 6 力月から長くても 1 年以内とす るべきであると考えられた。妊娠予後に関与する 因子として付属器癒着スコアについてみると、術 後妊娠例と非妊娠例の比較で、統計学的有意差は 認めたかったものの術後非妊娠例で付属器瘉着入 コアが高い傾向があった。年齢および不妊期間に ついては、術後妊娠例と非妊娠例との比較では有 意差はなかったが、年齢が35歳以上のもので術後 妊娠率が有意に低率であり、不妊期間が 4 年以上 のもので有意差はなかったが術後妊娠率が低率で あったことから、妊娠予後に年齢・不妊期間が影 響すると考えられた。

また今回の検討では、これら 3 つの因子以外に、 卵巣チョコレート襄胞の有無が術後妊娠予後に関 
与する因子として抽出されたことから、チョコレ 一ト襄胞に手術操作を加えることが術後妊娠予後 に影響していたと考えられた。チョコレート襄胞 に対する術式に関しては、当科では囊胞径 $3 \mathrm{~cm}$ 以 上を基準に囊胞摘出を行っており、今回の検討で は約70\%の症例が喠胞摘出を受けていた。囊胞摘 出術のほうが蒸散・焼灼術に比較して、術後妊娠 率が高くまた再発率が低いとこが示されているが9)、 その一方で囊胞摘出の際に正常卵巣組織の一部も 摘出されることで卵巣予備能を低下させるとする 報告もある ${ }^{10)}$ 。ただし、チョコレート襄胞に関し ては、妊孕性の問題だけでなく卵巣癌合併や将来 の癌化の問題もあり、日産婦の取扱い規約では襄 胞径が $4 \mathrm{~cm}$ 以上の場合には襄胞摘出が推奨されて いる。今回の検討では、チョコレート震胞を有す る症例の術後妊娠率は、囊胞摘出術施行例と内腔 焼灼術施行例との間に有意差を認めなかったこと から、妊孕性温存においていずれの術式が望まし いかを今回の結果のみで判断することは困難であ る。今後、霊胞径と術式、止血方法、術後卵巣予 備能および術後再発率などを含め詳細に検討し、 当科のチョコレート襄胞に対する手術療法を評価 する必要があると考える。

以上の成績より、子宮内膜症不妊症例において 腹腔鏡下手術を行うことは、付属器癒着の程度を 評価できること、また病巣除去により軽症例だけ でなく重症例でも術後ART以外での妊娠が期待で きることから有用であるといえる。ただし、軽症 例であっても最終的にARTを必要とした症例も存 在したことから、ART以外での妊娠を期待する期 間は長くても 1 年以内とするが、高齢の症例や不 妊期間が長期の症例では、早期のART導入を検討 する必要がある。

\section{【参考文献】}

1）日本産科婦人科学会編：子宮内膜症の取扱い規約，第 2 部, 治療編 ·診療編, 2010; 53-64, 金原出版

2 ) Kennedy S, Bergqvist A, Chapron C, et al: ESHRE guideline for the diagnosis and treatment of endometirios. Hum Reprod 2005; 20: 2698-2704

3 ) The Practice Committee of the American Society for Reproductive Medicine. : Endometriosis and infertilily. Fertil Steril 2006; 86: S156-160

4) Jacobson TZ, Duffy JMN, Barlow D, et al: Laparoscopic surgery for subfertility associated with endometriosis. Cochrane Database Syst Rev. 2010; (1): CD001398.
5 ) Vercellini P, Sommigliana E, Vigano P, et al : Surgery for endometriosis-associated infertility: a pragmatic approach. Hum Reprod 2009; 24: 254-269

6 ) Osuga Y, Koga K, Tsutsumi O, et al : Role of laparoscopy in the treatment of endometriosisassociated infertility. Gynecol Obstet Invest 2002; 53 : 33-39

7 ) 北島道夫, 藤下 晃, カレク・ネワズ・カーンほか： 当科における子宮内膜症合併不妊症の検討. エンドメ トリオーシス研究会会誌 2005; 26: 29-35

8 ) 高橋絵理, 林 博, 齊籐隆和ほか: 子宮内膜症性不妊 症における腹腔鏡下手術の治療予後：特に卵管癒着ス コアと妊娠率の関連性. 日産婦内視鏡学会 2007; 23 : 252-256

9 ) Hart RJ, Hickey M, Maouris P, et al : Excisional surgery versus ablative surgery for ovarian endometriomata. Cochrane Database Syst Rev. 2008; (2): CD004992.

10) Busacca M, Vignale M: Endometrioma excision and ovarian reserve: A dangerous relation. J Minim Invasive Gynecol. 2009; 16(2): 142-148 